\title{
КЛАСТИЧЕСКИЙ МАТЕРИАЛ НЕОАРХЕЙСКОГО МОЛАССОИДНОГО КОМПЛЕКСА КОЙКАРСКОГО ДОМЕНА: ПЕТРОГРАФИЧЕСКАЯ И ГЕОХИМИЧЕСКАЯ ХАРАКТЕРИСТИКА И ОБСТАНОВКИ ФОРМИРОВАНИЯ
}

\section{Бакаева A.B.}

Институт геологии КарНЦ РАН, Петрозаводск sashe-ku@yandex.ru

Неоархейский молассоидный комплекс Койкарского домена (Центральная Карелия) сформировался на завершающих стадиях ( 2.65-2.60 млрд. лет) развития Ведлозерско-Сегозерского зеленокаменного пояса, предшествовавших этапу стабилизации Карельского кратона. Интерес к данному объекту вызван тем, что на основе анализа состава терригенных пород, можно реконструировать не только условия формирования осадочного бассейна, но и породных ассоциаций, выведенных в область эрозии до момента его заложения. А это в свою очередь позволит дополнить и уточнить историю формирования континентальной коры региона на границе мезо-неоархея.

Целью исследования является петрографическое и геохимическое изучение кластического материала полимиктовых конгломератов молассоидного комплекса (район оз. Питкилампи, детальное описание приводится в [3] и определение условий формирования пород, представленных в обломках конгломератов.

\section{Методы исследования}

Петрографическое изучение пород выполнялись с использованием поляризационного микроскопа «ПОЛАМ Р-312», содержания петрогенных элементов в пробах определялись методом силикатного анализа [2], концентрации редких и редкоземельных элементов измерялись на квадрупольном масс-спектрометре X-SERIES 2 Thermo scientific по методике [4]. Все работы проводились в Аналитическом центре Института геологии КарНЦ РАН (г. Петрозаводск).

\section{Результаты}

В рамках данного исследования выполнено петрографическое и геохимическое изучение кластического материала конгломератов неоархейского молассоидного комплекса в районе оз. Питкилампи. Результаты изучения цемента конгломератов приведены в работе [1]. В данной работе основное внимание уделялось галькам среднего и кислого состава, как наиболее сохранившимся элементам древней континентальной коры. В результате петрографических работ описаны основные типы пород, представленные в обломках. Выявлены гальки основного состава (базальтов, базальтовых коматиитов), размером (2-5)*(10-15) см, представленные мелкозернистыми, массивными породами с фибробластовой структурой, состоящими из хлорита, амфиболов, карбоната и редких зерен титанита и эпидота. Обломки средних и кислых пород представлены дацитами (доминируют в кластической части конгломератов), риодацитами, гранитами, плагиогранитами. Дациты - массивные, порфировые (бластопорфировые) породы с фибробластовой структурой основной массы, сложенной кварцем, хлоритом, плагиоклазом, мусковитом, эпидотом, карбонатом, редкими зернами титанита. Среди вкрапленников выделены зерна плагиоклаза (20-30 об. \%) и кварца (5-20 об. \%). Размер обломков (3-5)*(8-20) см. Граниты и плагиограниты массивные, среднезернистые с гипидиоморфнозернистой структурой, состоят из плагиоклаза (20-30\% об. \%), калиевого-полевого шпата (5-15 об. \%), кварца (10-20 об. \%), эпидота, серицита, рудного минерала и хлорита. Обломки пород кислого состава наиболее крупные в осадочном бассейне, их размер достигает (20-30)*(40-60) см.

Результаты петрохимического анализа галек согласуются с петрографическими наблюдениями: содержание $\mathrm{SiO}_{2}$ варьирует от 52.33 до 74.78 мас. \%, $\mathrm{Na}_{2} \mathrm{O}+\mathrm{K}_{2} \mathrm{O}-2.31-10.21$ мас. \%. Среди обломков выделяются породы основного, среднего и кислого состава (рис. 1). В связи с тем, что для молассоидных комплексов (тип Тимискаминг) характерно присутствие галек известково-щелочных и щелочных пород, одной из основных задач данного исследования был поиск подобного кластического материала в конгломератах, не представленного среди существующих в настоящее время магматических комплексов Койкарского домена. В результате работ были обнаружены гальки кисло- 

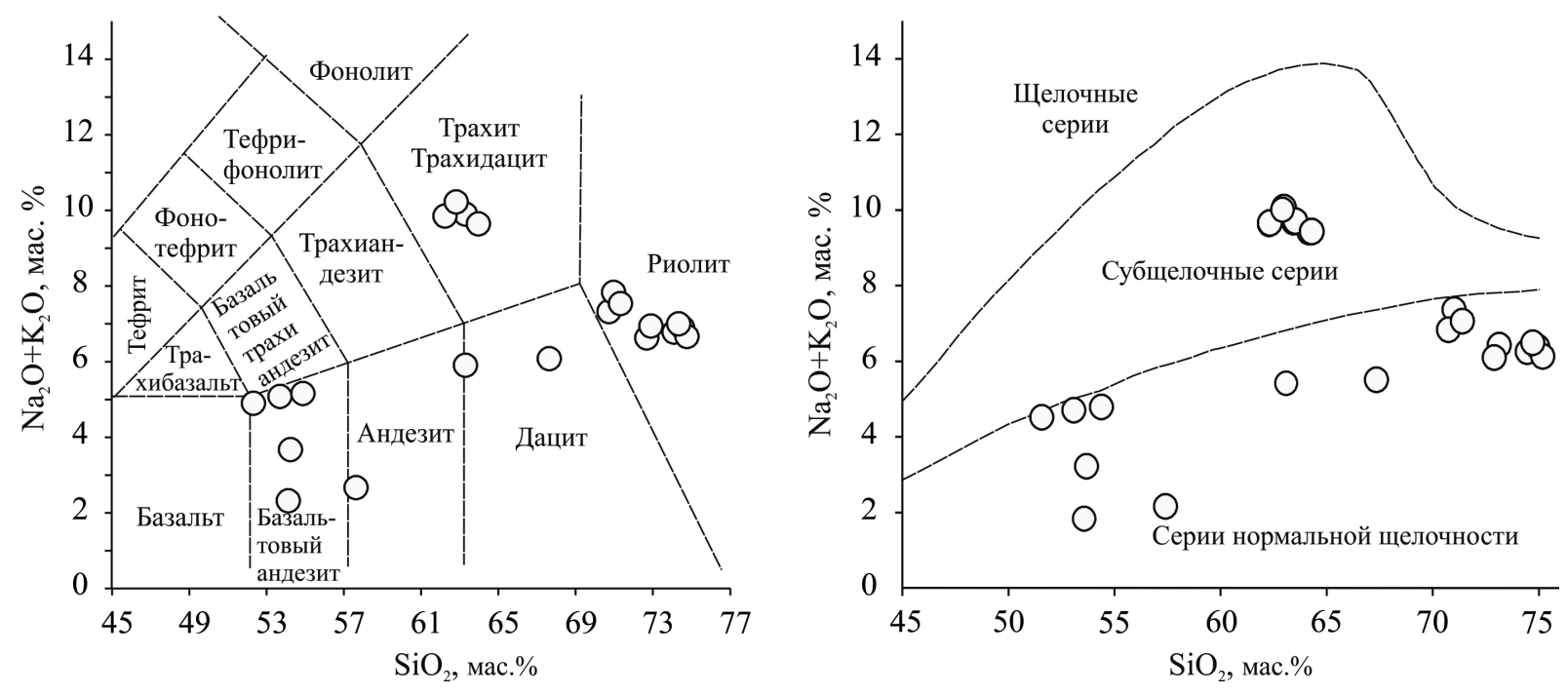

Рис. 1. Классификационные диаграммы $\mathrm{SiO}_{2}-\left(\mathrm{Na}_{2} \mathrm{O}+\mathrm{K}_{2} \mathrm{O}\right)$ для галечного материала молассоидного комплекса Койкарского домена.

го состава субщелочной серии с содержанием $\left(\mathrm{Na}_{2} \mathrm{O}+\mathrm{K}_{2} \mathrm{O}\right)$ от 9 до 10 мас. \%, по петрографическим данным относящиеся к трахидацитами и субщелочным гранитам, и гальки среднего состава близкие по содержанию щелочей $\left(\mathrm{Na}_{2} \mathrm{O}+\mathrm{K}_{2} \mathrm{O}=4.89-5.15\right.$ мас. \%) к базальтовому трахиандезиту (рис. 2).

Для классификации средних и кислых пород и определения потенциальных геодинамических обстановок их формирования, были рассмотрены концентрации $\mathrm{Nb}, \mathrm{Ta}, \mathrm{Rb}, \mathrm{Y}, \mathrm{Yb}$ в обломках и представлены на дискриминационных диаграммах Дж. Пирса (рис. 2 А, Б, В).
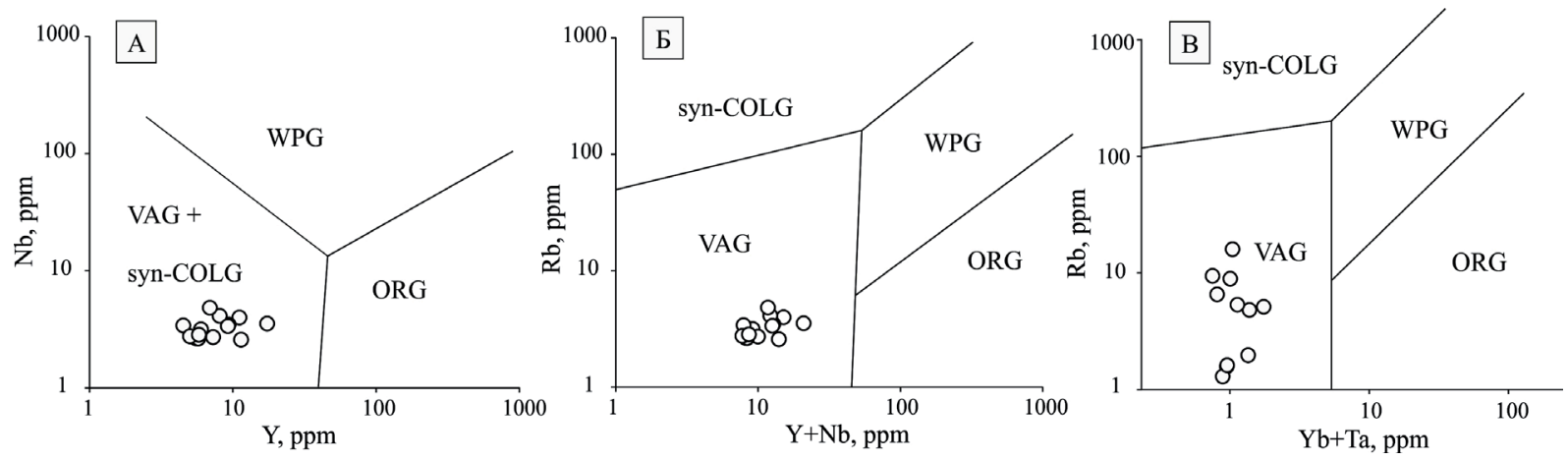

Рис. 2 Дискриминационные диаграммы $\mathrm{Nb}-\mathrm{Y}(\mathrm{A}), \mathrm{Rb}-(\mathrm{Y}+\mathrm{Nb})$ (Б), Rb-( $\mathrm{Yb}+\mathrm{Ta})$ (В) Дж. Пирса [6] для среднего и кислого кластического материала полимиктовых конгломератов неоархейского молассоидного комплекса Койкарского домена. VAG - граниты вулканических дуг; ORG - граниты океанических хребтов; WPG - внутриплитные граниты; syn-COLG - коллизионные граниты.

Положение фигуративных точек на диаграммах рис. 2 (Б, В) демонстрирует геохимическую приуроченность кислого материала конгломератов (в том числе и субщелочных пород) к породам вулканических дуг (VAG), образующихся в пределах океанических дуг и активных континентальных окраин.

На диаграмме $\mathrm{Th} / \mathrm{Yb}-\mathrm{Nb} / \mathrm{Yb}$ (рис. 3) положение фигуративных точек составов кислой кластики соответствует области обогащения Тh относительно $\mathrm{Nb}$, что может происходить в случае формирования исходных магматических пород в результате субдукционных процессов, контаминации первичными выплавками корового материала или определяться влияния состава мантийного источника [5]. Принимая во внимание концентрации $\mathrm{Nb}$, Ta, Rb, Y и Yb в гальках конгломератов (рис. 2), можно предположить, что наиболее вероятными обстановками формирования источников кислого материала являлись вулканические дуги. 


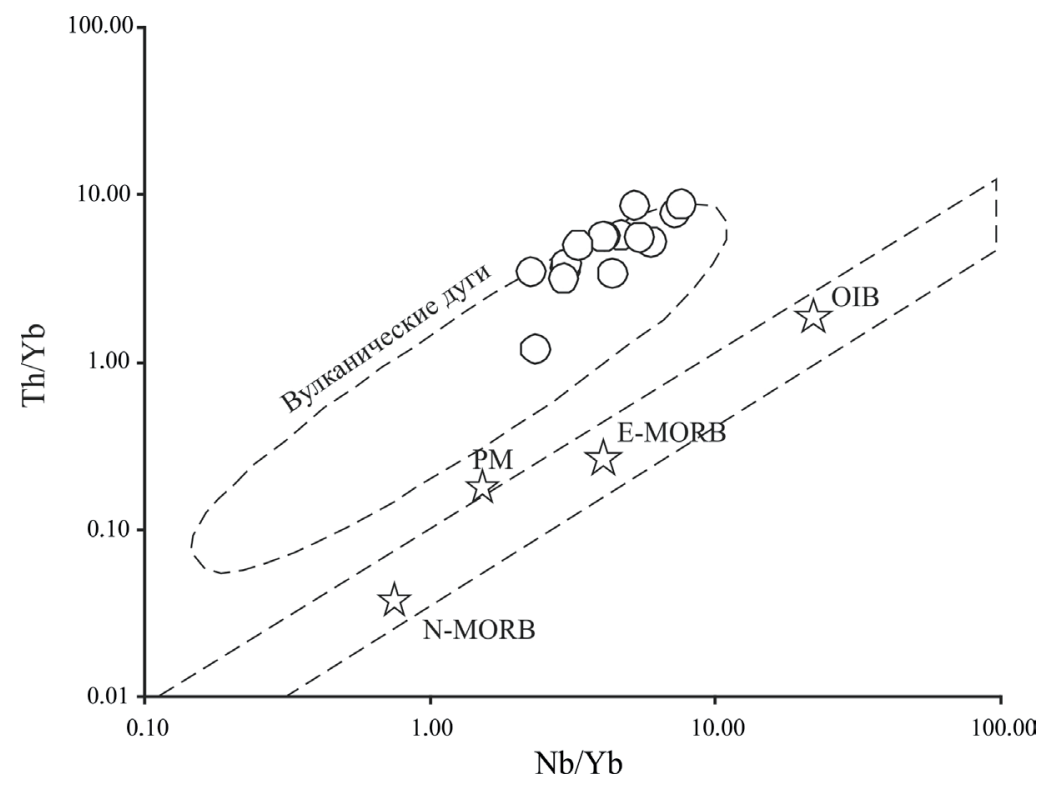

Рис. 3. Вариационная диаграмма $\mathrm{Th} / \mathrm{Yb}-\mathrm{Nb} / \mathrm{Yb}$ [5] для галек полимиктовых конгломератов неоархейского молассоидного комплекса Койкарского домена.

\section{Выводы}

1. В результате петрографических исследований были получены данные об основных типах пород, доминирующих в кластическом материале полимиктовых конгломератов неоархейского молассоидного комплекса Койкарского домена, представленных основными породами (базальтами, базальтовыми коматиитами) и породами среднего и кислого составов (андезитами, дацитами, риолитами, гранитами, плагиогранитами);

2. Результаты геохимического изучения пород согласуются с петрографическими наблюдениями, по содержанию $\mathrm{Na}_{2} \mathrm{O}+\mathrm{K}_{2} \mathrm{O}$ среди кластического материала установлены породы субщелочной серии (рис. 1);

3. Изучение распределения концентраций редких элементов $(\mathrm{Nb}, \mathrm{Ta}, \mathrm{Rb}, \mathrm{Y}, \mathrm{Yb})$ и отношение $\mathrm{Th} / \mathrm{Yb}$ и $\mathrm{Nb} / \mathrm{Yb}$ в кластическом материале позволяют предположить, что вероятной обстановкой формирования первичных магматических пород являлась вулканическая дуга, приуроченная к зоне субдукции.

Данное исследование показало перспективность для региона детального изучения кластического материала для реконструкции утраченных, в результате эрозии, магматических систем и позволяет существенно дополнить существующие представления о развитии Карельского кратона на границе мезо-неоархея.

Работы выполнялись в рамках госзадания ИГ КарНЦ РАН.

\section{Литература}

1. Бакаева А.В. Матрикс полимиктовых конгломератов неоархейского молассоидного бассейна Койкарского домена: геохимическая характеристика, источники материала // Труды Карельского научного центра РАН. № 2. 2018. С. 111-121. DOI:10.17076/geo766.

2. Пономарев А.И. Методы химического анализа силикатных и карбонатных горных пород. Издательство АН СССР. Москва. 1961. 414 с.

3. Светов С.А. Магматические системы зоны перехода океан-континент в архее восточной части Фенноскандинавского щита. Петрозаводск: КарНЦ РАН. 2005. 230 с.

4. Светов С.А., Степанова А.В., Чаженгина С.Ю., Светова Е.Н., Рыбникова 3.П., Михайлова А.И., Парамонов А.С., Утицына В.Л., Эхова М.В., Колодей В.С. Прецизионный (ICP-MS, LA-ICP-MS) анализ состава горных пород и минералов: методика и оценка точности результатов на примере раннедокембрийских мафитовых комплексов // Труды КарНЦ РАН. 2015. Т. 7. С. 54-73. doi: 10.17076/geo140.

5. Dampare S.B., Shibata T., Asiedu D.K., Osae S., Banoeng-Yakubo B. Geochemistry of Paleoproterozoic metavolcanic rocks from the southern Ashanti volcanic belt, Ghana: petrogenetic and tectonic setting implications // Precambrian Res. 2008. V. 162. P. 403-423.

6. Pearce J.A., Harris / V.B.W., Tindle A.G. Trace element discrimination diagrams for the tectonic interpretation of granitic rocks // J. Petrol. 1984. V. 25. P. 956-983. 